J.B. ELEUBAEVA ${ }^{1}$

"JSC "Kazakh Institute of Oncology and Radiology," Almaty, the Republic of Kazakhstan

\title{
The historical foundations and current status of diagnostic cytology at the Kazakh Institute of Oncology and Radiology (to the 60th anniversary of the Institute)
}

The article talks about the origins of cytological service in Kazakhstan and the 60-years' history of its development at the Kazakh Institute of Oncology and Radiology (KazIOR) and describes the merits of the service veterans and their contribution to cytology. The author sketches the current state and promising directions of clinical cytology development at KazIOR.

Keywords: History of cytology, the founders of cytological service, cytological studies.

Central Cytology Laboratory exists in Kazakhstan since the establishment of the Kazakh Institute of Oncology and Radiology (KazIOR) in 1960. The Republican Centralized Cytological Center created at KazIOR by order of the Ministry of Healthcare of the Republic of Kazakhstan dated 29 December 1991 coordinates the organizational-methodological (35 practical guidelines issued), scientific (18 candidate's theses defended), and practical activities in the field of clinical cytology at all levels starting with the primary health care level.

This order has established cytology centers in all regions and two cities (Almaty, Astana) to form a national cytology service that functions to the present day. The service workers - highly qualified cytologists - do clinical cytology and participate in state screening programs.

The Cytology Laboratory conducts diagnostic, research, advisory, and preventive research focusing on the urgent problems of cytological diagnostics of tumors and precancerous diseases, the automation of cytological stud- ies and early cancer screening as part of targeted preventive examinations of the population of Kazakhstan. KazIOR has trained high-quality cytologists who work throughout the country. The resident researchers - Candidates of Medical Sciences A.M. Aisarova and R.G. Kozbagarova, Doctor of Medical Sciences A.I. Shibanova et al. - have contributed a lot to the training and preparation of cytologists for oncology dispensaries of the Republic.

O.S. Isyutina was the first head of the Cytological Laboratory. The Laboratory staff included the cytologists G.B. Privman-Shubina, M.I. Aimaganbetova; the first researchers in clinical cytology were the Candidates of Medical Sciences A.M. Aisarova, R.G. Kozbagarova, and N.S. Kubasheva, and the Doctors of Medical Sciences Tolmachev and A.I. Shibanova. The first Cytology Laboratory assistants were M.N. Tyukina, G.N. Utebaeva, R.S. Togyzbaeva, and B.Kh. Kabieva. They contributed to developing various staining modifications and became experts in preparing high-quality glass preparations (Figure 1).

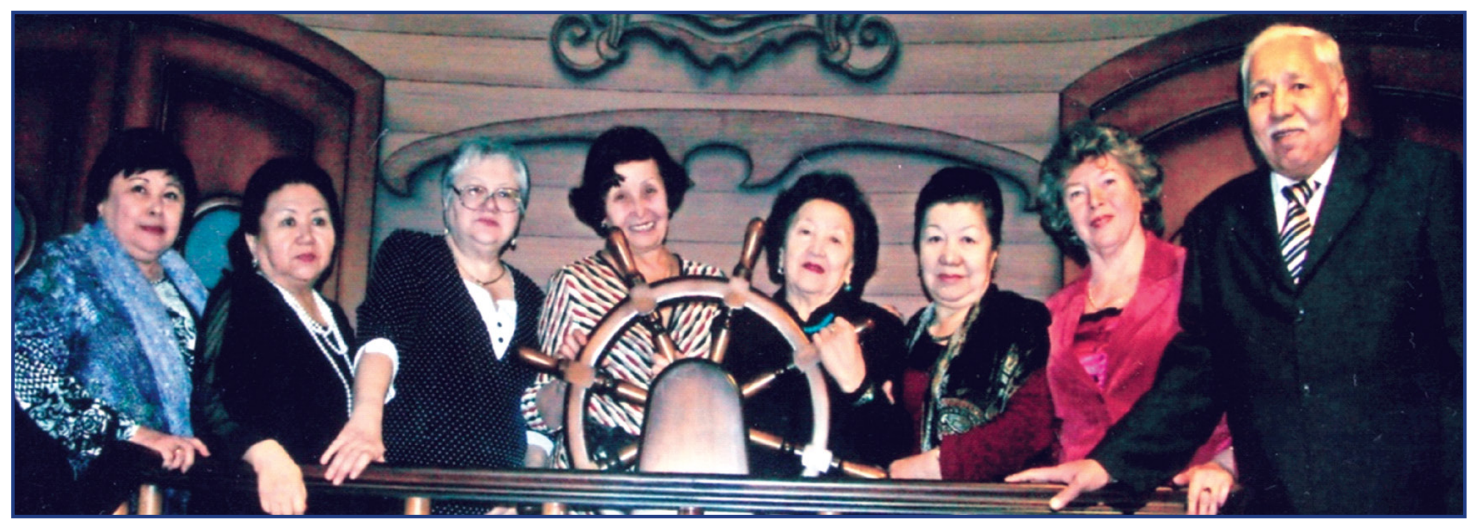

Figure 1 - Veterans-cytologists of KazIOR

Along with the development of practical clinical cytology, the staff of the Central Cytology Laboratory (Figure 2) was engaged in the development of scientific areas of cytology with a focus on the urgent problems of cytomorphological diagnostics of tumors and precancerous diseases, the automation of cytological studies, cytological examination in diagnosing dysplastic conditions and early cancer detection during mass preventive examinations (screening). The results of these scientific studies were included in the In- ternational Cytological Classification of the CMEA Member Countries (1976-1986) for diseases of the esophagus and endometrium. The scientific research was conducted using modern techniques such as immunocytochemical, DNA morphometric studies, and liquid cytology in screening.

The results of scientific research at the Central Cytology Laboratory were the basis for defending 18 candidate's theses in clinical cytology, publishing more than 500 scientific papers, and developing 45 practical guidelines. 


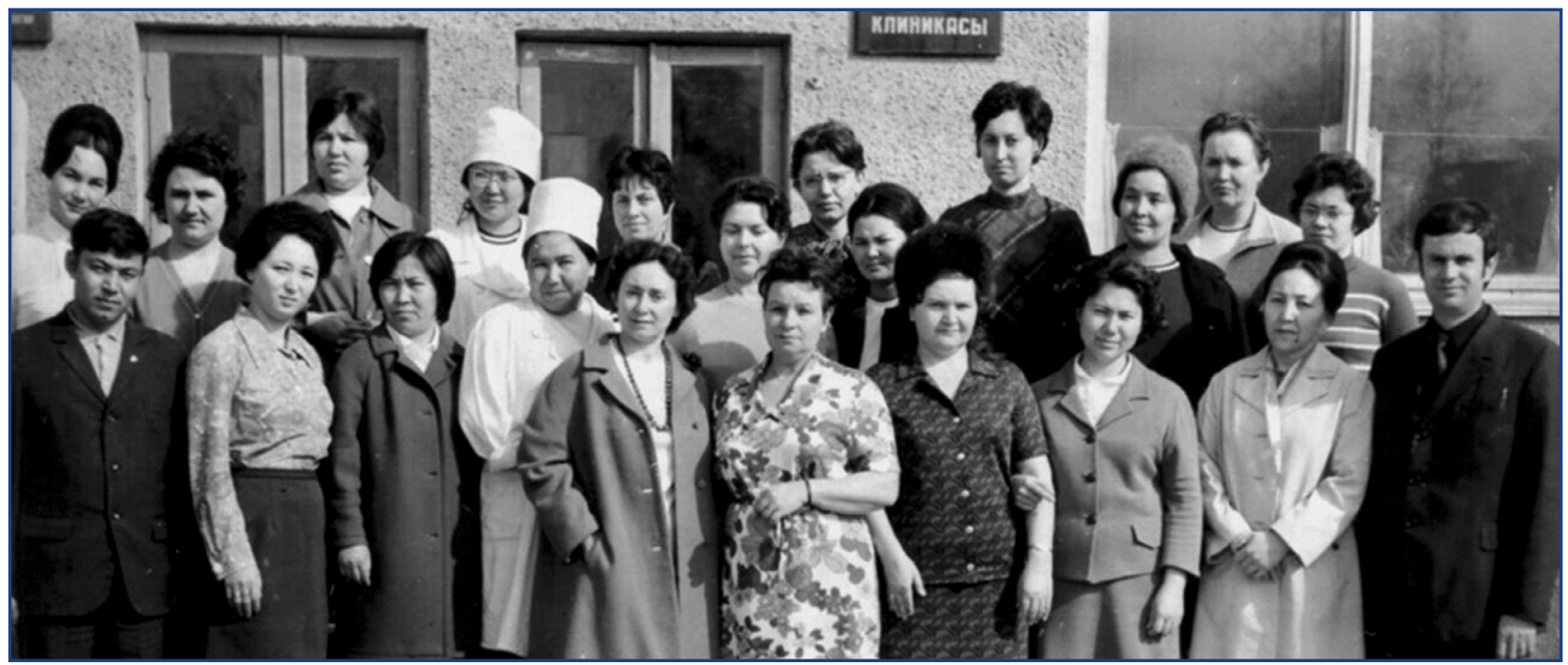

Figure 2 - The Cytology Laboratory staff, with other colleagues

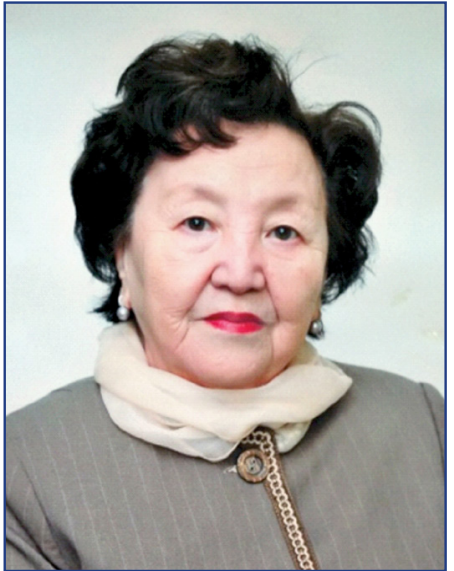

Figure 3 - Azat llyasovna Shibanova, Doctor of Medical Sciences, Professor, one of the founders of the discipline "Clinical Cytology" in the Republic of Kazakhstan

Azat llyasovna Shibanova (Figure 3 ), Doctor of Medical Sciences, Professor, one of the founders of the discipline "Clinical Cytology" in the Republic of Kazakhstan, headed the Cytology Laboratory at KazIOR from 1969 to 2006 and was the Chief Cytologist at the Ministry of Healthcare of the Republic of Kazakhstan. Prof. A.I. Shibanova has made an enormous contribution to the creation in 1993 of the Association of Clinical Cytology of Kazakhstan, a collective member of the International Academy of Cytology. For many years, Prof. Shibanova has been the regional editor for the Republic of Kazakhstan of the international journal "Acta Cytologica." She has been awarded the "Badge of Honor," the jubilee medal "For Valiant Labor," and the Order of "Kurmet" [Respect] (2020).

A.I. Shibanova was awarded the Al-Farabi medal of the 1 st degree for her achievements in scientific research. In 2006, the American Biographical Institute named her an expert in clinical cytology. In 2007, the International Biographical Center (Cambridge, UK) introduced her name in the list of 2000 intellectuals of the XX century and awarded the Silver Medal of the University of Cambridge.

In 2012, the Laboratory employees A.I. Shibanova and Zh. B. Eleubaeva were awarded the Sanofi award, a diversified leader in healthcare.
Currently, A.I. Shibanova is the Honored President of the RK Association of Cytology. She continues vigorous scientific and practical activities, is actively involved in training clinical cytologists and introducing new technologies in Kazakhstan.

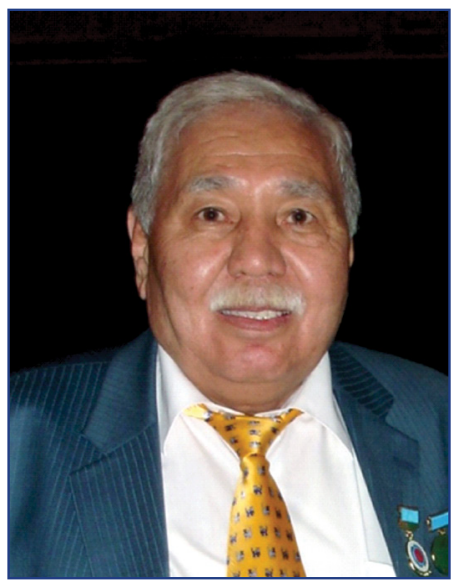

Figure 4 - Timur Zhuragatovich Turmukhanov, cytologist

Timur Zhuragatovich Turmukhanov (Figure 4) has 45 years of experience working as a cytologist at KazIOR. He chaired the RK Association of Clinical Cytology in 2016-2020. Timur Zhuragatovich takes an active part in training cytologists at the Cytology Laboratory of KazIOR, cooperates with the Pathological Anatomy Department of the Kazakh Medical University of Continuing Education. He undertook internships at scientific centers and oncology clinics of Moscow, Kyiv, Tbilisi, Almaty, etc. As an experienced and devoted cytologist, Timur Zhuragatovich is a constant organizer of cytomorphology conferences, oncology congresses, seminars and masterclasses for cytologists at KazIOR. He authored 35 scientific papers in various medical journals and collections of works of scientific conferences, was awarded the badges "Excellent Healthcare Worker," "Veteran of Labor," and many honorary diplomas of the RK Ministry of Healthcare and KazIOR.

Current employees of the Cytology Laboratory - B.T. Kusainova, Candidate of Medical Sciences N.A. Mukhametkaliev, Zh.B. Eleubaeva - are students and followers of 
Prof. Shibanova (Figure 5). They have the highest medical category. N.A. Mukhametkaliev headed the Cytology Laboratory of KazIOR in 2006-2011, the cytopathologist Zh.B. Eleubaeva - in 2011-2013. Since 2006, N.A. Mukhametkaliev and Zh.B. Eleubaeva are members of the International Academy of Cytology, European and Japanese As- sociations of Cytopathologists; they regularly speak at international congresses (including in Paris (France) in 2013, in Seoul (Korea) in 2014, in Geneva (Switzerland) in 2015, in Yokohama (Japan) in 2016, in Beppu (Japan) ) in 2017, in Sapporo (Japan) in 2018, in Malmo (Sweden) in 2019) and continue to work at KazIOR.

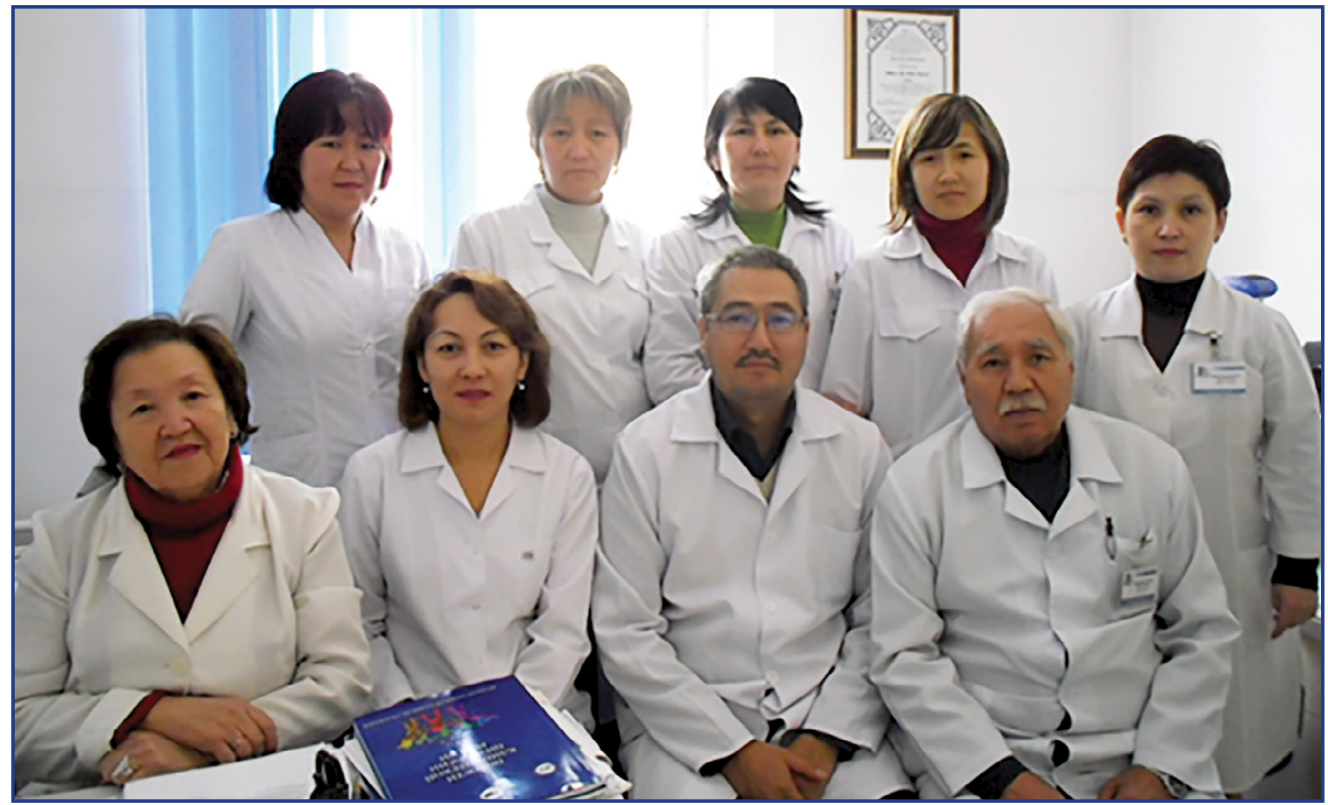

Figure 5 - Laboratory staff, with Professor A.I. Shibanova

Doctors of KazlOR continually prove their competence and professionalism at national and international levels. In 2016, Zh.B. Eleubaeva, the Freelance Chief Specialist of the Ministry of Healthcare of the Republic of Kazakhstan on cytology, has successfully passed an international exam and was assigned an international FIAC status as expert-researcher in cytopathology. She authored 60 scientific papers and books, including "The cytological diagnosis of diseases of the esophagus, stomach, and intestines" (Moscow, 2011). Her paper "Cytological diagnostics of cervical cancer" published in Japan in 2020 summarized the results of a year of re- search at Nagasaki Atomic Bomb Impact Research Center (Japan).

Mastering new technologies, including fine needle biopsy for preoperative diagnostics of tumors, is the most promising way to improve the cytology diagnostics quality, particularly in early cancer detection. Differential diagnostics in various neoplastic diseases is based on immunocytochemical studies using cell blocks, which are successfully used in many leading clinics of the world. Acting cytopathologists of KazIOR support the clinicians in timely verification of various neoplastic diseases using various morphology methods to examine both cytological and operating materials.

\section{ТҰЖЫРЫМ}

\section{Ж.Б. Елеубаева ${ }^{1}$}

««азақ онкология және радиология ғылыми-зерттеу институты» АҚ, Алматы, Қазақстан Республикасы

\section{КазОжРҒЗИ-дағы диагностикалық цитологияның тарихи негіздері және қазіргі жағдайы: Институттың 60 жылдығына}

Мақалада Қазақстандағы иитологиялық қызметтің бастаулары, ҚазОжРҒЗИ қызметінің 60 жыл ішіндегі даму тарихы туралы тарихи деректер ұсынылған, сондай-ақ ардагер-цитологтардың еңбегі және олардың ғылымға қосқан үлесі сипатталған. ҚазОжРҒЗИ-дағы клиникалық цитологияның қазіргі жағдайына қысқаша сипаттама беріліп, оны дамытудың перспективалық бағыттары сипатталған.

Түйінді сөздер: Цитология тарихы, қызмет негізін қалаушылар, Цитологиялық зерттеулер.

\section{АННОТАЩИЯ}

\section{Ж.Б. Елеубаева ${ }^{1}$}

${ }^{1}$ А0 «Казахский Научно-исследовательский институт онкологии и радиологии», Алматы, Республика Казахстан

\section{Исторические основы и современное состояние диагностической цитологии в КАЗНИИОИР: к 60-летию института}

В статье представлены исторические данные об истоках читологической службы в Казахстане, истории развития службы за 60 лет деятельности КазНИИОиР, а также описаны заслуги ветеранов-цитологов и их вклад в науку. Дана краткая характеристика современного состояния и описаны перспективные направления развития клинической цитологии в КазНИИОиР.

Ключевые слова: История цитологии, основатели службы, читологические исследования. 